\title{
Comparing rockfall scar volumes and kinematically detachable rock masses
}

\section{Introduction}

Scenario-based risk assessment for rockfalls, requires assumptions for different scenarios of magnitude (volume). Extreme rockfall events can be defined as those that are characterised by the detachment of rockfall masses of one or more orders of magnitude greater than the commonly observed events in an area. In practice, common methodologies for the rockfall hazard assessment may involve an individual block or many blocks of different sizes (Ferlisi et al. 2012).

In the first case, some researchers propose the use of the average rock size (Abbruzzese et al. 2009, Li et al. 2009) or the mostly expected one (Pierson et al. 1990). However, extreme events, albeit rare, can be highly destructive or disruptive, and should be taken into account for a proper risk assessment and management. When rockfall classes are used instead, the expected volumes for a given study site can be introduced into the quantitative hazard and risk assessment through the establishment of magnitude-frequency relations (Corominas et al. 2014). The incorporation of rockfall magnitude scenarios into the risk analysis has also been proposed by Agliardi et al. (2009), Barlow et al. (2012), Lari et al. (2014) and Macciotta et al. (2015). The volumes to be expected in a study site are commonly defined using statistical distributions such as power law based on empirical data (Dussauge et al. 2003, Hantz et al. 2003, Budetta et al. 2015, Hungr et al. 1999) or using data deriving from the geo-structural representation of the rock mass (Hantz et al. 2003, Hoek and Bray 1981, Ferrari et al. 2015). During the last decades, the alternative use of remote sensing techniques (Abellan et al., 2011) permits the compilation of inventories with precise information on the rockfall volume.

The maximal rockfall size is commonly assumed to be the greatest inventoried one, independently of the rock mass properties. Malamud et al. (2004), Picarelli et al. (2005), and Dussauge-Peisser et al. (2002) suggested the extrapolation of power-law magnitude-frequency relations, for a preliminary assessment of the largest events. Instead, the geo-structural representation of the rock mass allows for considering the local characteristics of the jointed rock mass such as continuity lengths of the discontinuity sets and spacings. These characteristics might be a possible reason for the truncation of the afore-mentioned distributions, as some rockfall (Ruiz-Carulla et al. 2015a) and other landslide inventories (Turcotte et al. 2002) indicate.

The in-situ block size distribution (Elmouttie and Poropat 2012 and Ruiz-Carulla et al. 2015b) has been associated with unstable volumes and the failure geometry of the rock face (Kalenchuk et al. 2006, Ferrero et al. 2011). Palmström (2005), proposed the block volume to be evaluated in function of the joint spacing and geometric disposition and the volumetric joint count (Palmström, 1982). Lu and Latham (1999) outlined the importance of the fractal dimensions of the three sets of discontinuity spacing values delimiting a volume. Lu (1997), introduced an additional "relative impersistence factor", $F_{\text {imp }}$, to take into account the effect of not fully persistence discontinuities, on the block volume.

These studies focus on the most likely to occur or the mean block size. Nevertheless, maximum volumes can be evaluated using the same assumptions as proposed by these studies, but in function of the maximum values spacings. In any case, the use of the in-situ block size volumes for the 
assessment of the expected rockfall volumes, disregards the potential for detachment, from the slope face, of assemblies of blocks instead of individual ones.

To assess assemblies of potentially unstable blocks and to approximate their volumes in search of big volume events, a detailed engineering geological mapping of the entire rock face and the potentially unstable rock masses on it can be performed (Saroglou et al. 2012, Copons 2005). This technique is mainly based on the detection of open joints and kinematically unstable rock masses. However unstable volumes are not always visible on the slope surface. For assessing the stability of block assemblies, too, Yarahmadi Bafghi et al. (2003) suggested the key-group method that takes into account the presence and intersection of discontinuities in the rock mass. However, this method presents limitations for its massive application on a rocky slope, in order to detect the biggest volumes. Additionally it requires information on the persistence of the discontinuities inside the rock mass, which is seldom available.

The afore-mentioned procedures can be mostly applied for the detection of the commonly observed rockfall sizes in an area, and do not contemplate extreme events which might be produced under the presence of particularly adverse conditions. The establishment of an extreme maximum but realistic rockfall volume for a given study site, still remains a challenge.

The assessment of the maximum credible rockfall volume at a rocky slope presents several uncertainties, including different, although inter-related issues. These include: a) The role of the joint orientation, spacing, and persistence, limiting the detachment of large blocks (Brady and Brown 1992; Kim et al. 2007, Palmstrom et al. 2001, Elmouttie and Poropat 2012, Lambert et al. 2012, Wyllie and Mah 2004); b) the scale analysis which will determine whether the smaller blocks bounded by persistent discontinuities inside larger ones that might failure individually from the first-order larger blocks will be taken into consideration. For the investigation of the maximum rockfalls, just the firstorder larger blocks may be considered; and (c) the failure mechanisms, including structurally controlled failure of individual blocks, step-path failure of blocks linked by rock bridges, rock mass failures in intensely fractured rock masses. Instability is much more likely to occur if spacings are dense and joints are fully persistent, given the usually much higher resistance of intact rock compared to that of joints (Einstein et al. 1983). Nevertheless, Kim et al. (2007) outlined that as joint spacing gets wider, brittle failure of the intact rock mass is more likely to occur and also bigger rock blocks are expected. Moreover, greater rock blocks are expected for not fully persistent joints than for fully persistent ones. Einstein et al. (1983), Frayssines and Hantz (2006) suggested that most discontinuities are not fully persistent and that, during rock slope failure, a complex interaction occurs between preexisting discontinuities and brittle fracture propagation through intact rock bridges. This failure mechanism was termed "step-path" failure by Jennings (1970). Brideau et al. (2009) outlined its importance especially for large rock slope failures.

Rock stability analysis may include these effects according to its level of sophistication. Stead et al. (2006) indicated three levels of increasing complexity, varying from the conventional application of kinematic and limit equilibrium techniques to simulate simple failures to the use of numerical continuum-discontinuum codes with fracture simulation capabilities, well suited to complex instabilities. Prior to all types of analysis, the modelling requires effective data collection in the field and data interpretation for potential failure modes with reference to the field observations. The use of LIDAR and photogrammetry techniques have permitted the collection of that data (Sturzenegger and Stead 2009, Jaboyedoff et al. 2012).

In this direction, the scope of this paper is to discuss the data that has been obtained from previous studies by detailed engineering geological mapping, combined with point cloud (Santana et al. 2012), 
and GIS data analysis (Mavrouli et al. 2015), with focus on the maximum realistic rockfall volume that can be expected at a given study-site in Andorra.

The study-site is a rocky slope situated next to the urban area of Santa Coloma, known as Forat Negre (Figure 1). Its special interest lies in its intense rockfall activity, posing a threat to buildings, infrastructure and persons at the adjacent built area. Important funds have been invested by the Government of Andorra for the installation of highly dissipative steel fences to retain and decelerate falling blocks. Yet a residual risk is attributed to the rock blocks that cannot be retained by protective barriers (Corominas et al. 2005), due to excessive energy or bouncing height. This risk can be associated to potential extreme events, which implies the need for an extensive investigation of a realistic maximum rockfall volume.

In Forat Negre, the rockfall size volume distribution has been investigated using two independent analyses. The first analysis (Santana et al. 2012) aimed at measuring the dimension of the scars produced by past rockfalls, in order to obtain information on the volume distribution of previous events. The measuring was performed by means of a point cloud obtained with a Terrestrial Laser Scanner, TLS. The second analysis (Mavrouli et al. 2015) focused on detecting kinematically detachable rock masses on a Digital Elevation model, DEM, applying the Markland criteria (Markland 1972) at each cell of the DEM. The joining of adjacent cells on the DEM where the same unfavourable discontinuities outcropped represented unstable zones. The distribution of the potential rockfall volumes at these zones was calculated, in function of the unstable zone areas on the DEM, and then transformed into equivalent volumes.

A brief description of the two analyses is included here. Their results serve as a starting point for the objectives of this work, which are (i) to compare the fundamental assumptions for the evaluation of the size-distribution of the scars and of the cinematically detachable rock masses and to discuss their differences; (ii) to relate the maximum assessed volumes with these assumptions; (iii) to discuss the role of joint persistence in the establishment of a maximum rockfall volume, for the study site; and (iv) to suggest realistic failure mechanisms for extreme rockfalls in the study area with reference to the field observations related to the persistency of the joints and the size of the rockfalls and the analysed data. 


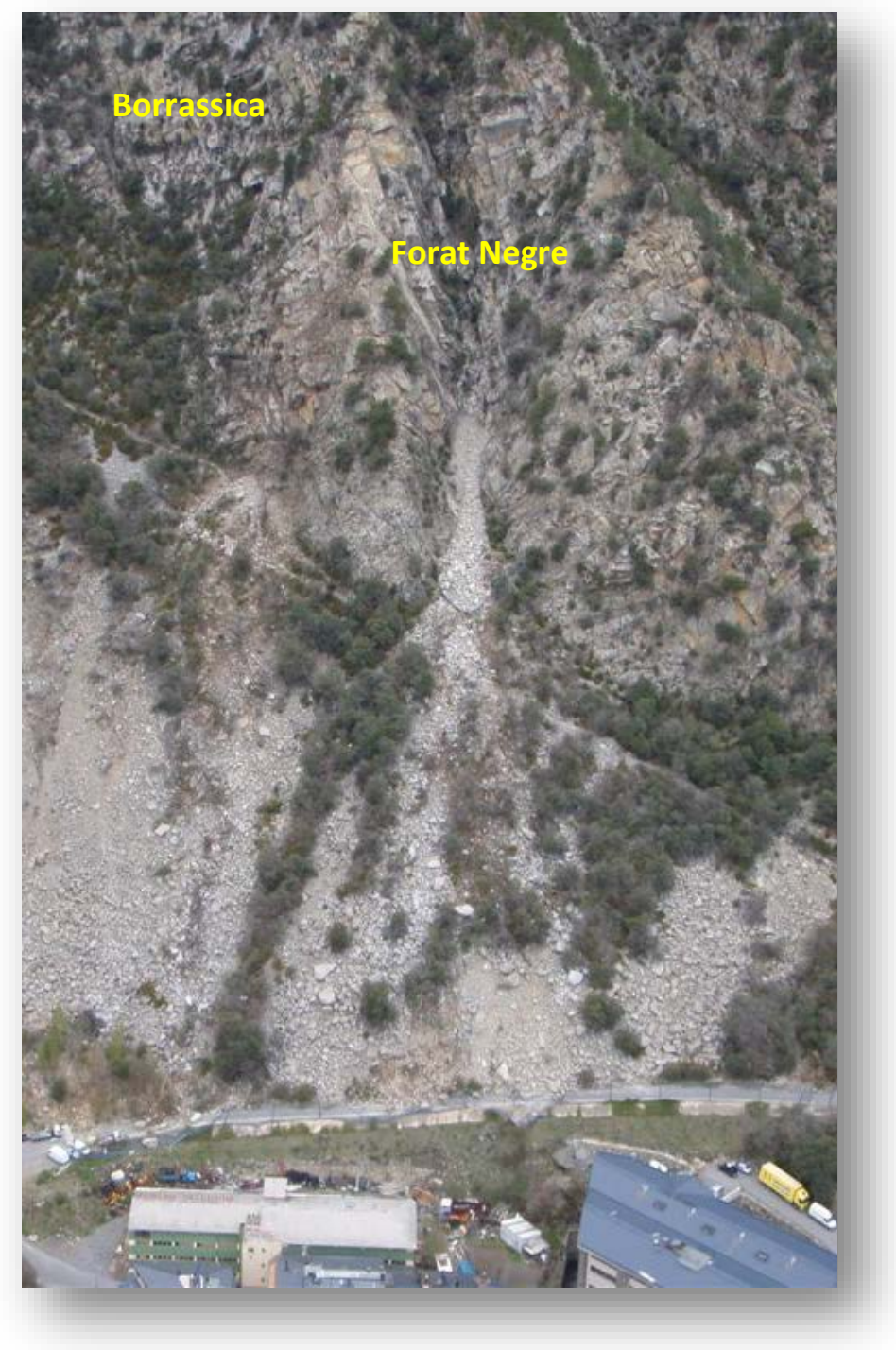

Fig. 1 The slope above the town of Santa Coloma and the chute of Forat Negre (Foto credit: Joan Torrebadella)

This study, that includes the investigation of the results for the previously calculated maximum volumes, focuses on the determination of the factors that are related to the jointed rock mass and affect the maximum credible rockfall volume. It aims at identifying the conditions and failure modes that permit or impede the occurrence of a biggest rockfall event and to propose the determining factors that should be analysed at similar case studies. This is a first step of an on-going work towards the determination of credible detachment mechanisms of big rockfall events in the study site.

\section{The study site}

The Solà d'Andorra is a rocky slope, about $2 \mathrm{~km}$ long and with a maximum altitude of 2179 meters, above the urban areas of Andorra la Vella and Santa Coloma in the Principality of Andorra. As 
described at Corominas et al. (2005) during the Pleistocene period the glaciers invaded the Valira valleys and attained thicknesses of several hundred meters the main phase of glacier retreat started 40000 years ago (Bordonau 1992). At Andorra la Vella the glacial erosion produced an over-deepend depression of the valley floor which is now filled with lacustrine, deltaic and fluvial sediments to a depth of 50-60 m. Erosive feature and the presence of till deposits abandoned in the slopes indicate that, at this location, glaciers reached a thickness of $350 \mathrm{~m}$, and their erosion produced steep slopes up to a height of $1300 \mathrm{~m}, 300 \mathrm{~m}$ above the present valley foot. The northern side of the valley is formed by the Carroi massif, composed of granodiorite rocks and the slope of the Solà d'Andorra develops at its foot.

Various rockfall scars, chutes, screes and talus deposits indicate the occurrence of a high rockfall activity in the area, produced by the combination of several mechanisms such as stress-relief, freezethaw weathering, wedging by thee roots and raise of cleft water pressures from rainfall. Repeated rockfalls have produced fan-shaped talus cones at the foot of the rock cliffs.

The general average frequency is 1 event every 2 years. Zones with intense activity are Forat Negre, its adjacent zone Borrassica (Figure 1) and the distant zone of Bassera Mateu (Corominas et al 2005). The average annual rainfall precipitation is of $1071.9 \mathrm{~mm}$. A direct relation with the rainfall precipitations that might trigger a rockfall has not been established so far.

A rockfall that occurred in 1997, causing major damage of a building due to the impact of a block of $25 \mathrm{~m}^{3}$, raised the public awareness of the risk and the local authorities were mobilized to take action against rockfalls. A prevention policy was applied through three work plans (Copons et al. 2005): the rockfall master plan (related to construction permissions), the mitigation plan (with reference to the installation of structural protective measures) and the surveillance plan (focused on the location of possible future rockfalls and documentation of past ones).

The delimitation of hazard zones and the calculation of the energy against the protective barriers, for the rockfall master plan and the mitigation plan, have been performed using a representative block volume. This volume was calculated considering the size of the deposited blocks on the scree, as well the size of potentially unstable blocks detected on the slope face (Copons et al. 2005). Neither plan considers the potential of a big volume event, which implies several impacts at a time and possibly a mass movement.

This work investigates this potential in the chute of Forat Negre. It is a steep $\mathrm{V}$ shaped couloir formed in the Southern slope of the Enclar peak $(2383 \mathrm{~m})$. The couloir extends from $990 \mathrm{~m}$ to about $1300 \mathrm{~m}$ a.s.I. The rock mass is intensely fractured granodiorite. Since approximately 1968,11 rockfall events have occurred with a maximum recorded rockfall of $150 \mathrm{~m}^{3}$ (April, 2008) that destroyed extensively the rock barriers and damaged an unoccupied building located in a high hazard area, according to the rockfall master plan. So far, the biggest observed event in the wider area has been of $1000 \mathrm{~m}^{3}$ (zone of Tartera de la Pica, April 1969).

\section{Rockfall volume analysis}

The two analyses for the assessment of the rockfall scar size and the kinematically detachable rock masses have been included here. Detailed information on the methods can be found in Santana et al. (2012) and Mavrouli et al. (2015). Only the results which are exclusively related to the maximum rockfall volumes are presented here. 


\subsection{Rockfall scars}

The analysis of Santana et al. (2012) focuses as well on the chute of Forat Negre. It estimates the size distribution of the rockfalls that occurred in the past, measuring the size of the scars that have been produced by the detachment of rock masses from the slope face, forming the actual topographical relief. This distribution is an indicator of the rockfall activity over the last thousands of years. For this technique, point cloud data obtained by a Terrestrial Laser Scanner was used. This was proposed as an alternative to the evaluation of the rockfall frequency-magnitude relation based on historical records and reconstructed series of events, where this information is incomplete or unavailable.

As mentioned at Santana et al. (2012) during the application of this methodology, all the involved parameters were calibrated, comparing at several steps of the procedure, the generation of the rockfall scar areas with the lidar DEM relief and photos of the zone. As a validation, we were able to reproduce several reference scar areas identified on the photos and in situ and in particular the maximum ones. Neither by photos (qualitatively) or using the proposed method (quantitatively) have not observed rockfall scars with greater area than some hundreds of square meters.

The assessed size distribution was expressed in terms of volume of the rockfall masses that miss from the scars. The volume is the product of the scar base area with its height (Figure 2). The basic assumptions of this procedure are: (a) each scar basal plane corresponds to a unique rockfall, and (b) neighbouring scar basal planes with a step greater than $0.2 \mathrm{~m}$, define more than one events. The assumption (a) although might overestimate the volume corresponding to a rockfall scar, it provides conservative results for the determination of the maximum volumes for the case-study, which is the objective of this work. On the other hand, it does not consider the scenario of a rockfall leaving several scars on the rock face. This scenario was discarded for this work, given the fact that no big stepped surfaces can be observed in the field and that even for the greatest scars (Figure 10), the steps are low.
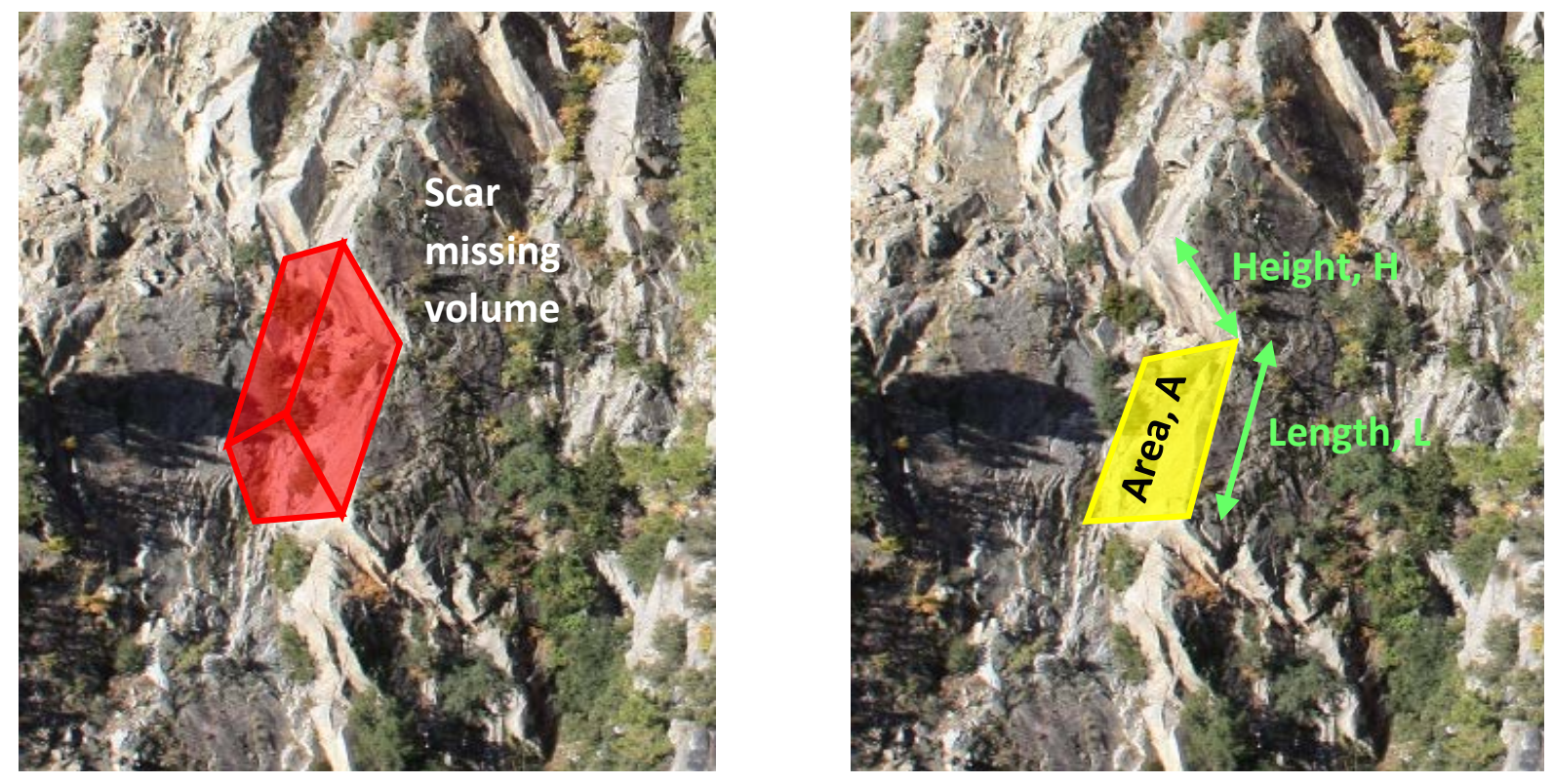
Fig. 2 Scar missing volume as the product of the scar basal area with its height

In the study area, the detachment of the rock mass from the slope takes, commonly, place along preexisting discontinuity sets, so that the scars edges are exposed planes of these discontinuities. The predominant failure mode is planar failure. For the study area, as only slight changes are observed on the relief, assuming a pre-failure topography parallel to the basal plane and defined by the tension crack dimensions is realistic. Thus a prerequisite for the application of the methodology was the definition of those sets. Figure 3 shows the dip direction and dip angle of sets defining kinematically detachable rock masses. The slops have an indicative dip direction of $160^{\circ}$.

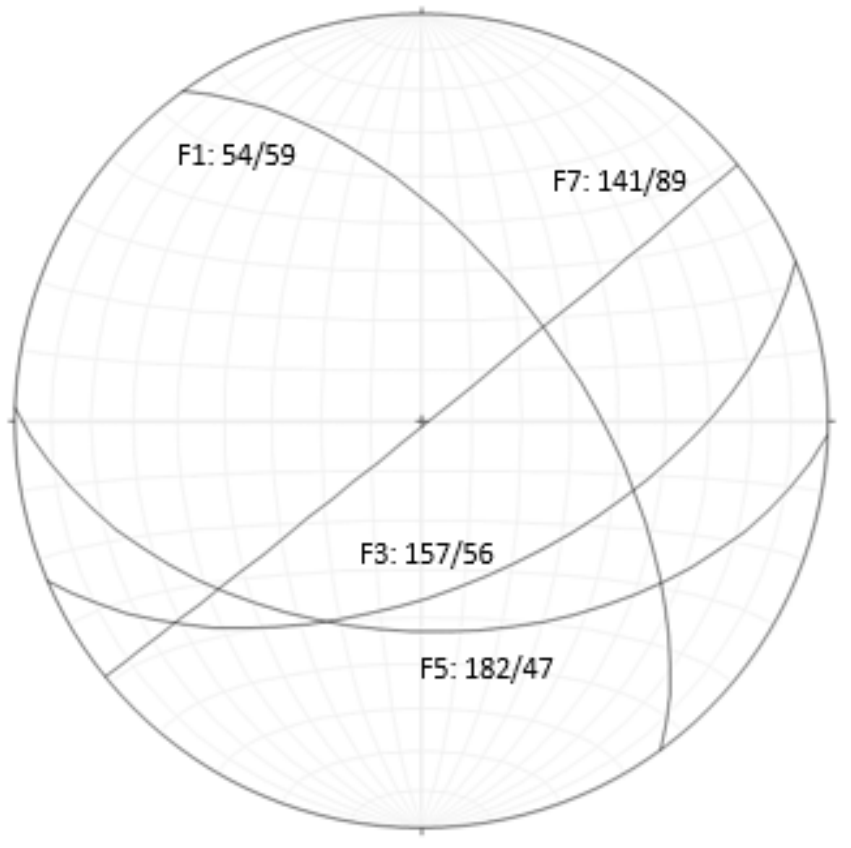

\begin{tabular}{lccl}
\hline $\begin{array}{l}\text { Discontinuity } \\
\text { set }\end{array}$ & $\begin{array}{c}\text { Dip direction } \\
\left({ }^{\circ}\right)\end{array}$ & Dip angle $\left({ }^{\circ}\right)$ & Role \\
\hline F1 & 54 & 59 & Lateral plane/tension crack \\
F3 & 157 & 56 & Basal sliding plane \\
F5 & 182 & 47 & Basal sliding plane \\
F7 & 141 & 89 & Tension crack \\
\hline
\end{tabular}

Fig. 3 Stereonet and joint characteristics

Rockfall scars mostly have prismatic shapes, which are formed by the intersection of 4 joint sets. The sets F3 and F5 alternate in the formation of sliding planes, or elsewise scar bases. They are drawn as polygons. They are intersected, almost perpendicularly, by F1 and F7 which play the role of lateral 
plane and tension crack. F1 and F7 are faults with large persistence. Figure 4 shows how the discontinuity sets intersect each other to form rock masses on the cliff face.

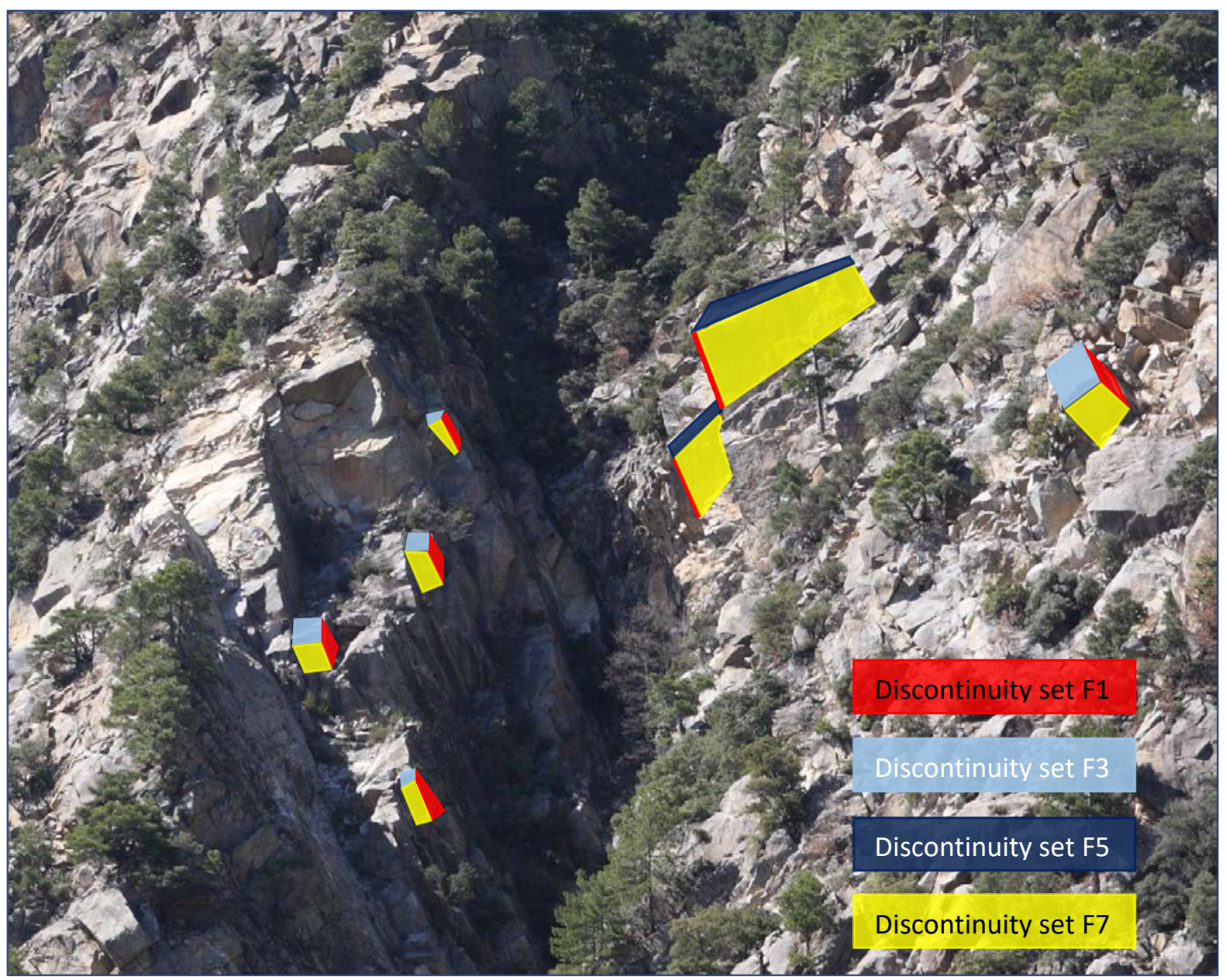

Fig. 4 Examples of intersection of discontinuity sets for the formation of rock blocks in the study-site

To measure the size distribution of the scars, the points of the point cloud belonging to each one of the four sets F1, F3 and F5, and F7 were filtered and planes were adjusted to them. These planes correspond to the scar edges. Their areas, the maximum width (along the strike) and length (along the dip) were measured. The heights of the scars are the intersections of the tension cracks F1 and F7, and their distribution was defined by the length (dip direction) of these planes. Eventually, the size distribution of the scars was calculated by means of a Monte Carlo simulation, multiplying the scar areas with the heights.

For a sample of 5000 scars, which is of the same order of magnitude as the identified scars on the point cloud, the maximum calculated scar volumes are of the order of few thousands of $\mathrm{m}^{3}(\sim 3000$ $\mathrm{m}^{3}$ ). This corresponds to the maximum rock mass size that has been detached actually from the slope face leaving a scar on it. The largest observed scar base was $213 \mathrm{~m}^{2}$, indicating a respective scar height of the order of $15 \mathrm{~m}$. 


\subsection{Kinematically detachable rock masses}

While the rock masses that are missing from the scars reveal the rockfall activity that took place in the past, the expected rockfalls in the future, can be associated with the unstable rock masses on the slope face. Following the procedure of Mavrouli et al. (2015), stability was defined after kinematic analysis based on the geometry of discontinuities and the slope orientation and angle. The size distribution of kinematically detachable rock masses was then calculated.

This analysis describes a conservative scenario such as that (a) the potential rockfall mass is detached entirely at a single rockfall event, without taking into account that smaller successive failures are possible instead, (b) the important joint sets are present all over the slope, and (c) the discontinuities outcrop at the lowest part of each cell. Following this procedure, no restriction is imposed on the rock mass detachment due to the existence of lateral confinement.

A GIS data analysis was performed to assess the zones of the slope that are unstable. This procedure consisted in using a raster DEM (cell resolution: $1 \mathrm{~m} \times 1 \mathrm{~m}$ ), derived from a topographical map at 1:5000 scale and covering the entire zone of Forat Negre. The selected cell resolution is enough to avoid inducing a significant error in the estimation of areas of hundreds or thousands of square meters. Kinematic analysis was performed at cell level to identify those cells that for the discontinuity sets F3 and F5 (the basal sliding planes), they fulfil the Markland instability criteria: (a) slope angle $>$ joint dip and (b) slope orientation=dip direction \pm 20 . No potential scenarios of wedge or toppling failure have been considered for the kinematic analysis, after observation of the failure mechanisms in the study area. These cells were marked on the DEM. Next, those of them that were adjacent were joined to form wider areas, of area A. Figure 5 resumes schematically this procedure. A prerequisite for the application of this method is that the discontinuities F3 or F5 are present at every cell of the DEM, and that they are fully persistent. 


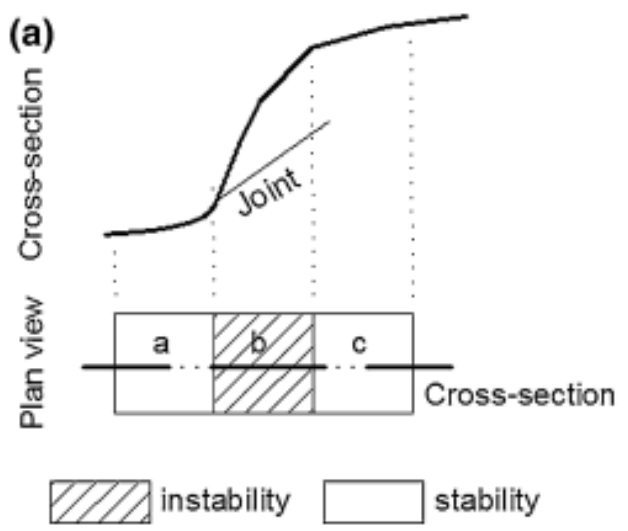

CASE I - pixel "b" is unstable according to the Markland kinematical test

- dip direction joint-dip direction slope $<20^{\circ}$ and

- joint dip angle < slope face angle

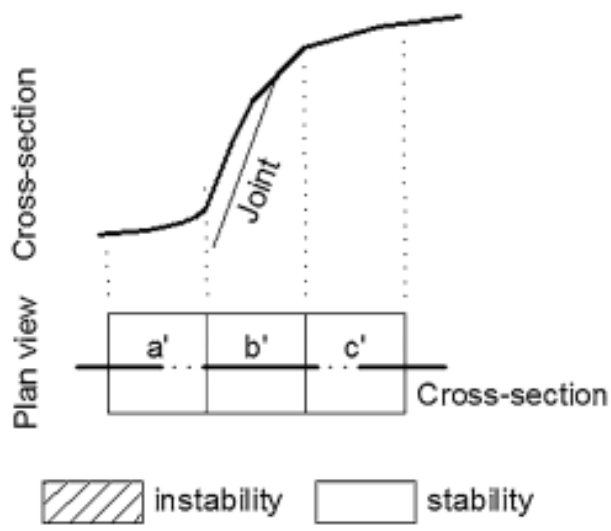

CASE II - pixel "b"' is stable according to the Markland kinematical test

- dip direction joint-dip direction slope $>20^{\circ}$ or

- joint dip angle > slope face angle

(b)

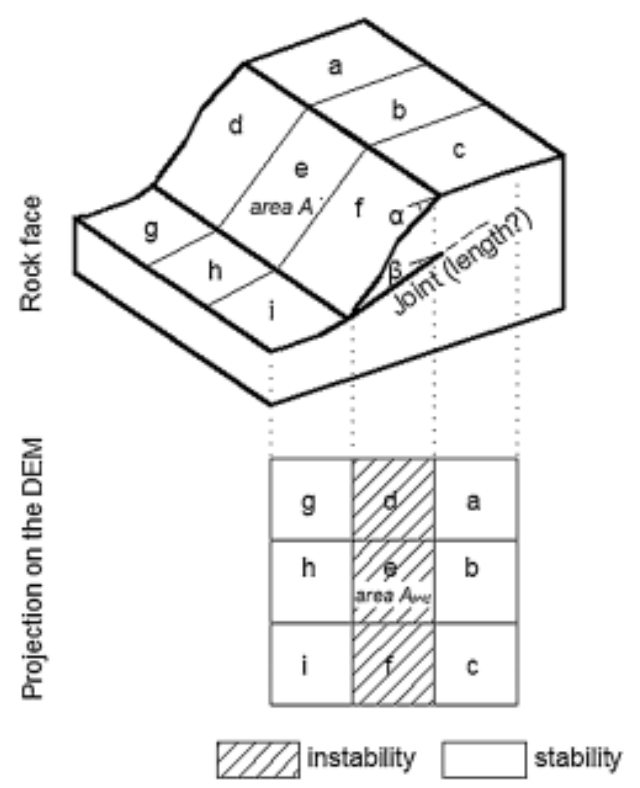

Fig. 5 Detection of kinematically detachable rock masses on a DEM. Left: (a) test of cell for instability and (b) formation of unstable areas by adjacent unstable cells (modified from Mavrouli et al. 2015)

The zones of the kinematically detachable rock masses were afterwards superposed on orthophotos to verify the instability. The most extensive zones are depicted in Figure 6. 


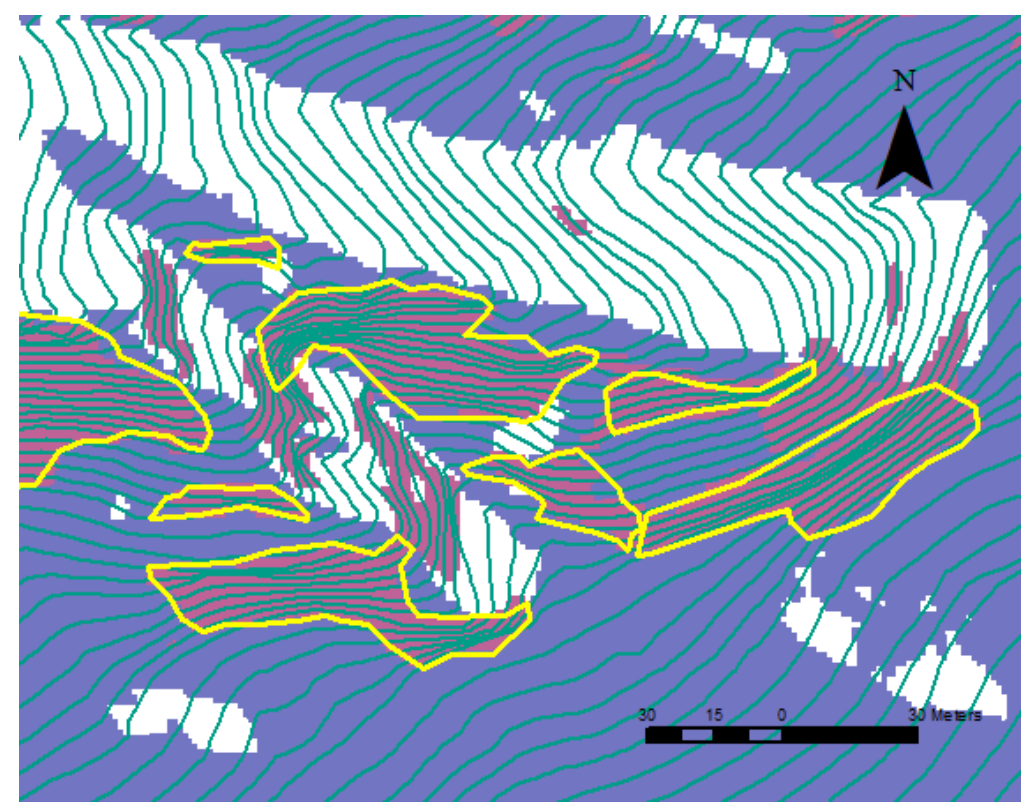

Fig. 6 The polygons in yellow are the areas on the DEM that fulfil the Markland instability criteria. In blue the cells with critical aspect (unfavourable F3 and F5 outcrops) and in purple the cells forming steep walls

The areas of these zones are indicative of the size of the rockfalls that might be expected in the studysite. To transform the area, A, into volume, $\mathrm{V}$, two alternative simplistic shapes of the detachable rock masses were assumed: cubic or prismatic. For both shapes, the base, corresponds to the area $A$. The height depends on the persistence of the basal plane inside the rock mass (see "joint length" in Fig. 4). For cubic shape this length is taken as $L=\sqrt{ } A$ and for prismatic as $L=0.5 \sqrt{ } A$. The cubic and prismatic volumes were respectively given by Equations (1) and (2).

$$
\begin{aligned}
& V=A^{3 / 2} \\
& V=0.5 A^{3 / 2}
\end{aligned}
$$

The maximum volumes obtained with this analysis were of the order of $50.000 \mathrm{~m}^{3}$ and $25.000 \mathrm{~m}^{3}$ for cubic and prismatic volumes accordingly. The largest calculated basal area was $1.361 \mathrm{~m}^{2}$. As the coexistence of all the afore-mentioned hypotheses (a) to (c) is lowly probable and the assumptions made for this analysis are very conservative (worst-case scenario), these volumes establish an upper limit for rockfalls in the study-site. In the following section, however, a discussion is carried out on whether these thresholds are credible.

4. Comparison of scar volumes with kinematically detachable rock masses 


\subsection{Assumption differences and effect on maximum rockfall volume}

The observed size distribution of the rockfall scars is an empirical evidence of past rockfalls. Instead, the kinematically detachable rock masses indicate hypothetical rockfalls that might occur in the future. Hence a comparison is made here between the empirical evidence of rockfalls and the calculated rockfall failures.

Despite the two diverse approaches in the analysis of the rockfall size distribution, the difference between the scar volumes ( $3000 \mathrm{~m}^{3}$ approximately) and the kinematically detachable rock masses ( 25000 or $50000 \mathrm{~m}^{3}$ respectively for prismatic and cubic volumes) is limited to 1 order of magnitude. This difference can be mainly attributed to the divergence of the analysis assumptions.

The calculation of the scar volumes is based on the joint traces length, which is that part of the discontinuities that after a rockfall remained exposed on the slope face. Thus, according to this analysis, the apparent extent of the discontinuity surface that is implicated in the detachment of the rock mass from the slope face is determined by the scar edges and it is limited. On the contrary, for the detection of the kinematically detachable rock masses, the discontinuities are considered more persistent, allowing them to deeply penetrate into the rock mass. Therefore, the extent of the discontinuity surface that is involved in the detachment is larger.

An additional difference refers to the presence of discontinuities on the rock mass. While for the observed scars the discontinuities planes are the real ones, for the calculated volumes it is accepted that the discontinuity planes F3 and F5 outcrop at every cell of the DEM, which is very conservative. In reality, the presence of the discontinuities depends on their spacing and persistence.

A further issue is the consideration of step-path failures. For the observed scar volumes step-path failures with steps smaller than $20 \mathrm{~cm}$ are considered as unique rockfalls, but failures with steps higher than $20 \mathrm{~cm}$ are associated to separate rockfalls. Instead, the calculated kinematically detachable rock masses do not contemplate step-path failures, but only the detachment along continuous basal planes. These basal planes, which are assumed to outcrop at the lowest part of the detected unstable zones, are the deepest possible ones, and thus provide the greatest possibly detachable rock masses. Any other sliding surface, as for example, along a step-path surface would hence yield smaller volumes.

These methodological assumptions may explain the magnitude difference between scars and predictive volumes. In fact, although the predictive rockfall failures assume that the big continuous planes up to $1361 \mathrm{~m}^{2}$ (shown in Fig. 5) might be possible, these planes are not observed on the actual slope, where the maximum detected area is $213 \mathrm{~m}^{2}$. Figure 7 shows a common mechanism for the formation of extensive continuous planes, when more than two intersecting discontinuities are involved. The detachment of blocks takes place, gradually in single blocks or all at once as a block assembly, along very persistent pre-existing discontinuity sets. The lack of evidence of this mechanism at the study-site was therefore investigated here in association with the persistence of the basal planes of F3 and F5 and the spacing of the tension cracks and/or lateral planes F1 and F7. 


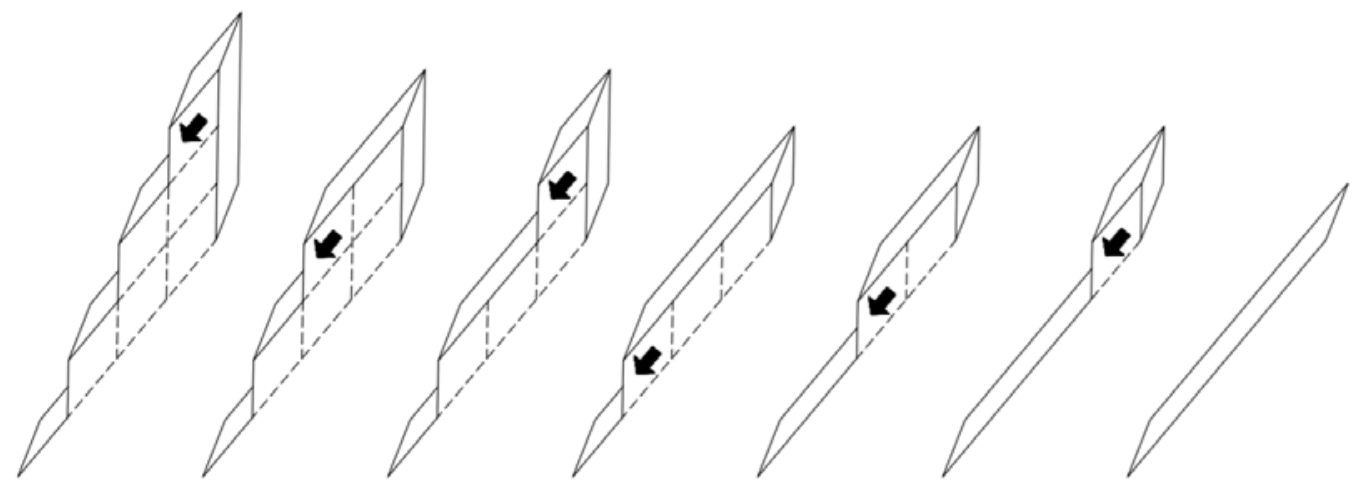

Fig. 7 Formation of large sliding planes through the gradual detachment of blocks along the preexisting discontinuities (the discontinuities inside the rock mass are drawn with dashed line). The simultaneous detachment of all blocks (large unique failure) would give the same result as well.

\subsection{Persistence and spacing}

After field reconnaissance, an interruption of the scar planes (discontinuities F3 and F5) was observed at their intersection with the tension crack and/or lateral planes F7 and F1. This interruption prevents the formation of large failures as shown in Figure 8.

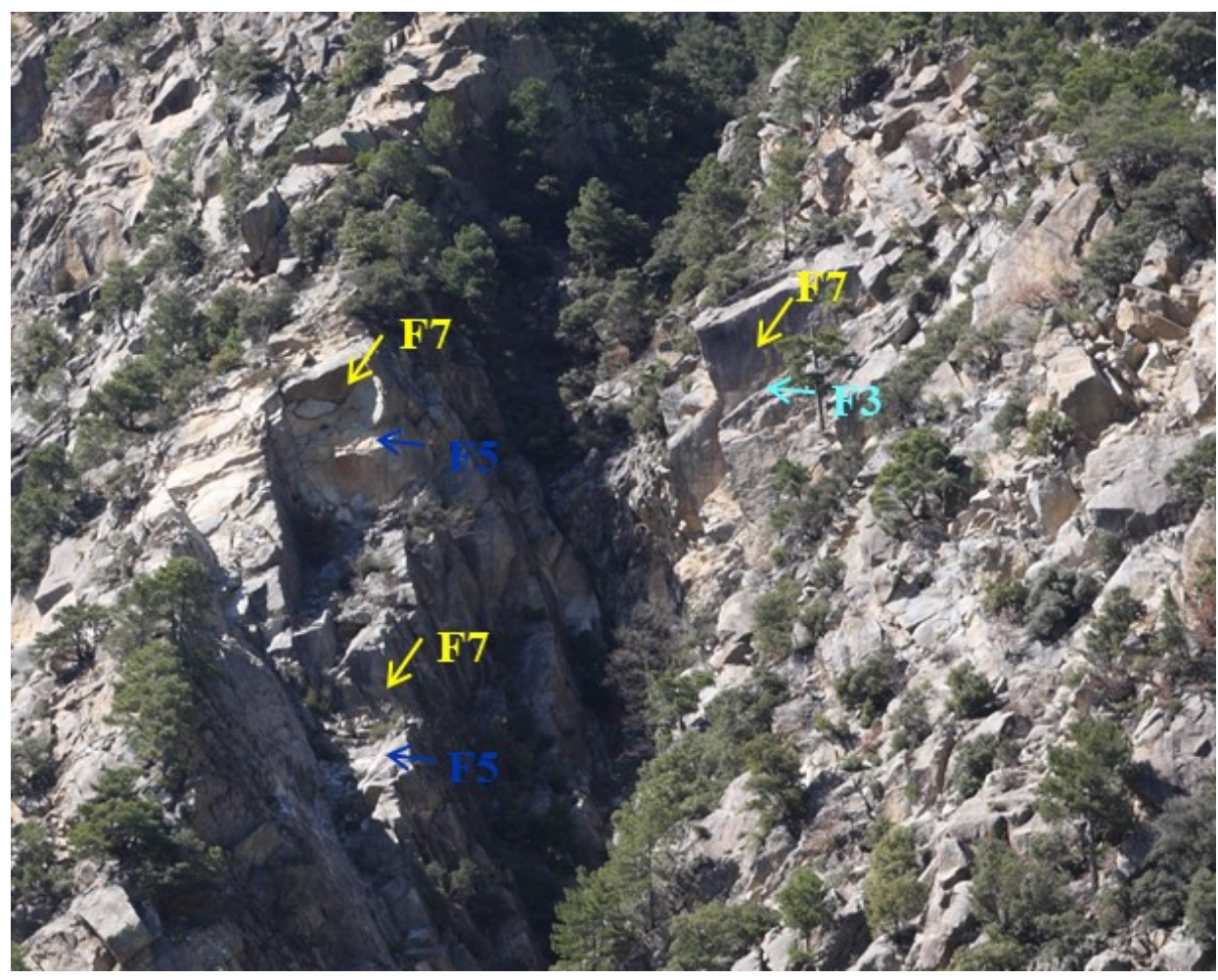

Fig. 8 Interruption in the persistence of large basal planes F3 and F5 by the tension crack planes F7 
The scar planes of Santana et al. (2012), permitted measuring the spacings of the discontinuity sets, as the perpendicular distances between successive planes $(254,162,104$ and 34 measurements for F1, F3, F5 and F7, accordingly). The software Rhinoceros was used to this aim. The spacing distributions are shown in Figure 9. It can be observed that the joint sets are highly present, with spacings up to few meters. Using the same data, the visible length (along the dip) of the scar edges was also calculated, as the maximum edge distance along the dip of a plane (Figure 10).

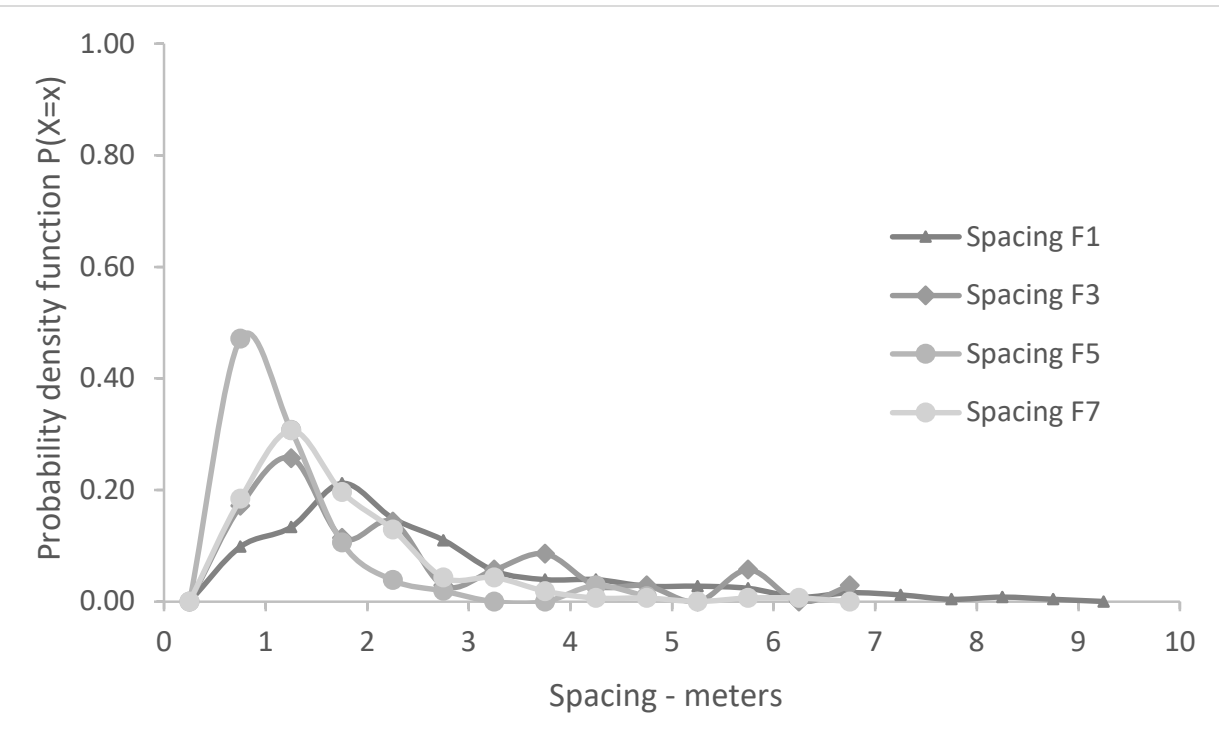

Fig. 9 Spacing distributions of the discontinuity sets

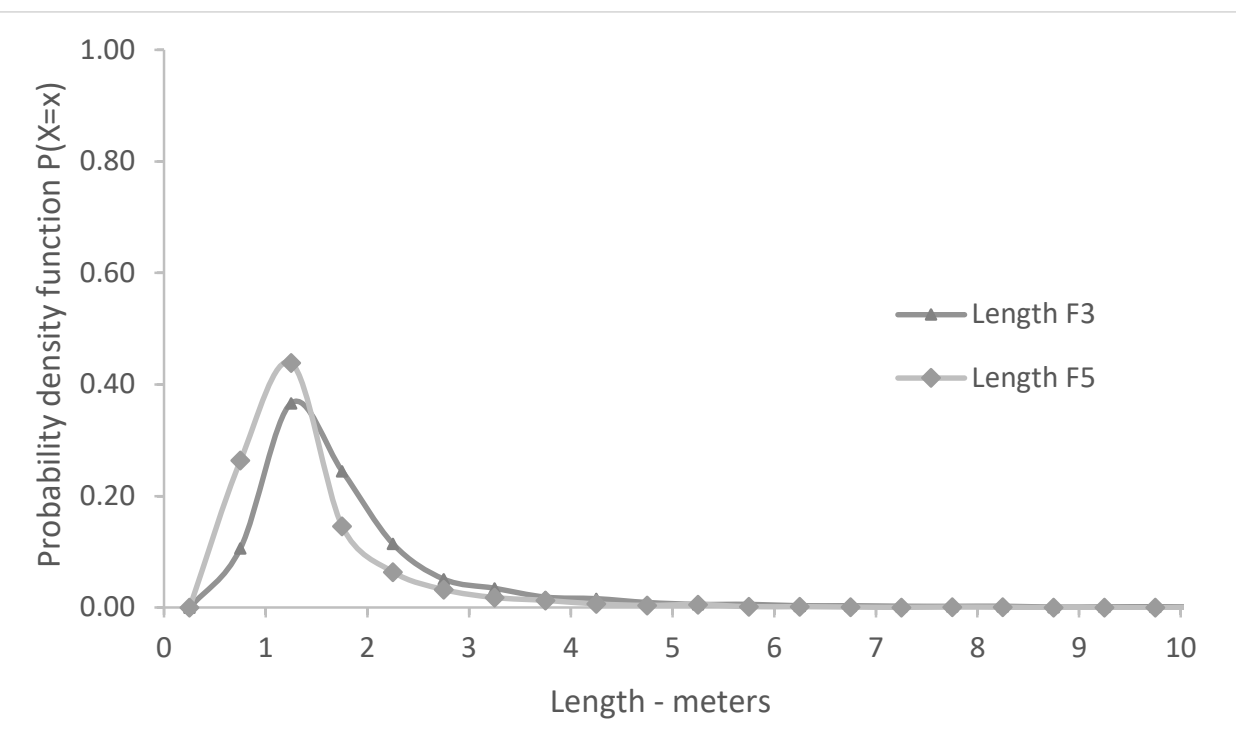

Fig. 10 Visible length distributions of the basal planes F3 and F5 


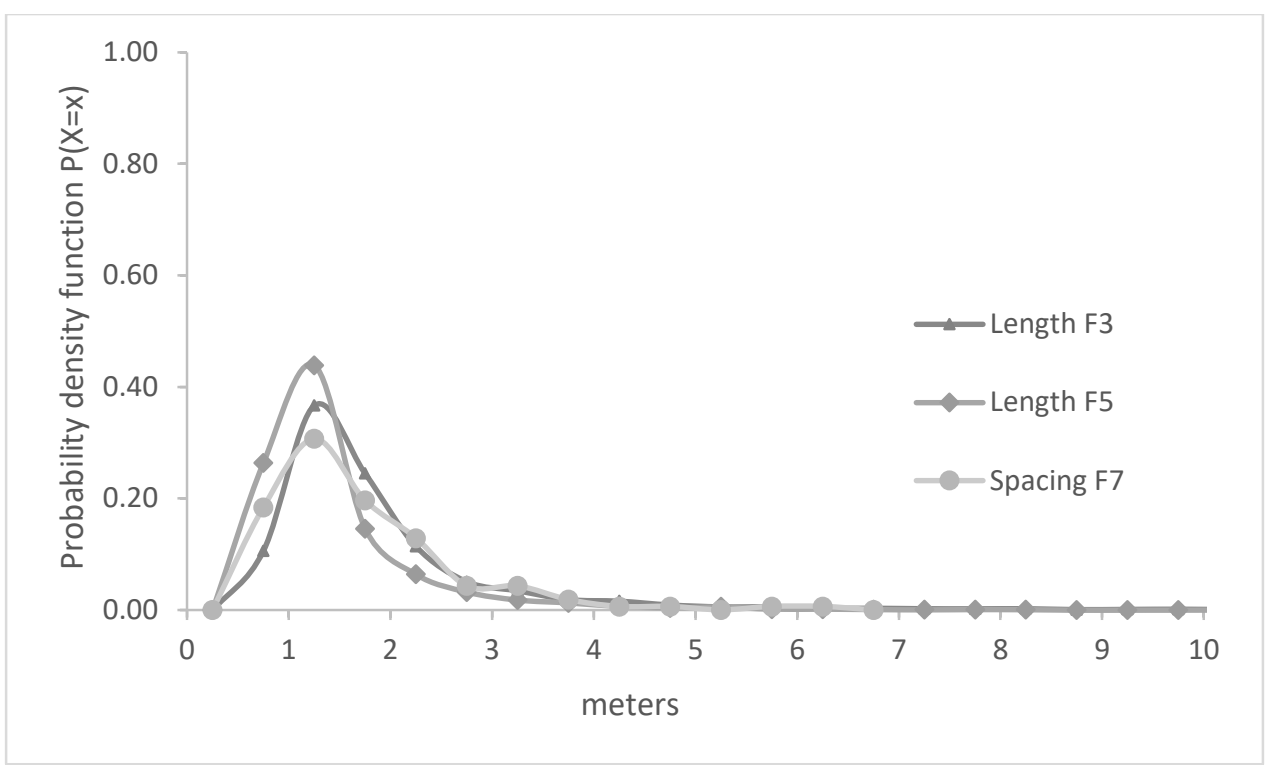

Fig. 11 Comparison of the F3 and F5 visible length distributions with the F7 spacing

Figure 11 indicates that the distributions of $\mathrm{F} 3$ and $\mathrm{F} 5$ (the basal instability planes) are very similar to the distribution of the planes of F7, although obtained by independent procedures. Table 1 summarizes the results for the maximum areas, average and median lengths. Their modal and average value are of the same order of magnitude. This, along with the visual observation of the exposed surfaces (Figure 7) that shows several planes of F3 and F5 being interrupted by F7 planes, suggests that in most cases F7 exerts a control over the length of the planes F3 and F5 limiting their persistence at their intersection. Hence for the study-site, the presence of F7, expressed by its spacing, plays a critical role in the determination of the maximum expected rockfall size, as it restricts the detachment of big rock masses. This factor makes the maximum credible volume for Forat Negre significantly smaller than the kinematically detachable rock masses.

Table 1 Measured areas and lengths of the scar edges and spacings of the discontinuity sets

\begin{tabular}{lrrrr}
\hline & $\mathrm{F} 1$ & $\mathrm{~F} 3$ & $\mathrm{~F} 5$ & $\mathrm{~F} 7$ \\
\hline Max spacing $(\mathrm{m})$ & 8.09 & 6.35 & 4.11 & 5.60 \\
Average spacing $(\mathrm{m})$ & 2.11 & 1.84 & 0.76 & 1.22 \\
Modal spacing $(\mathrm{m})$ & 1.63 & 1.22 & 0.53 & 1.00 \\
Max area $\left(\mathrm{m}^{2}\right)$ & 121 & 236 & 144 & 213 \\
Max length $(\mathrm{m})$ & 19.85 & 27.08 & 14.65 & 19.14 \\
Average length $(\mathrm{m})$ & 0.96 & 1.45 & 0.99 & 1.19 \\
Modal length $(\mathrm{m})$ & 0.76 & 1.04 & 0.73 & 0.89 \\
\hline
\end{tabular}

Nevertheless, a second observation arises from the results: In some cases, the planes of F3 and F5, that are the basal planes of the failures, are longer than the spacing of F7 that usually plays the role of tension crack. In fact, the maximum measured length of F3 and F5 $(27.08 \mathrm{~m}$ and $14.65 \mathrm{~m}$ respectively) is one order of magnitude longer than the spacing of F7. Some of these cases were 
localised on photos (Figure 11), demonstrating that for the study site, the rockfall failure does not always occur between two successive planes of F7; instead the formation of basal surfaces across more than one (although few) spacings of F7 is possible. For these areas, small steps, smaller than 20 $\mathrm{cm}$, could be recognised on the photos, suggesting the potential of a step-path failure, through the interaction of F3 and F5 with pre-existing discontinuities or minor brittle failures. As a conclusion, besides the detachment along continuous sliding planes, rockfalls may occur via step-path failures. The maximum volume will then depend on the length of the basal plane and the resistance of the rock bridges, if any.

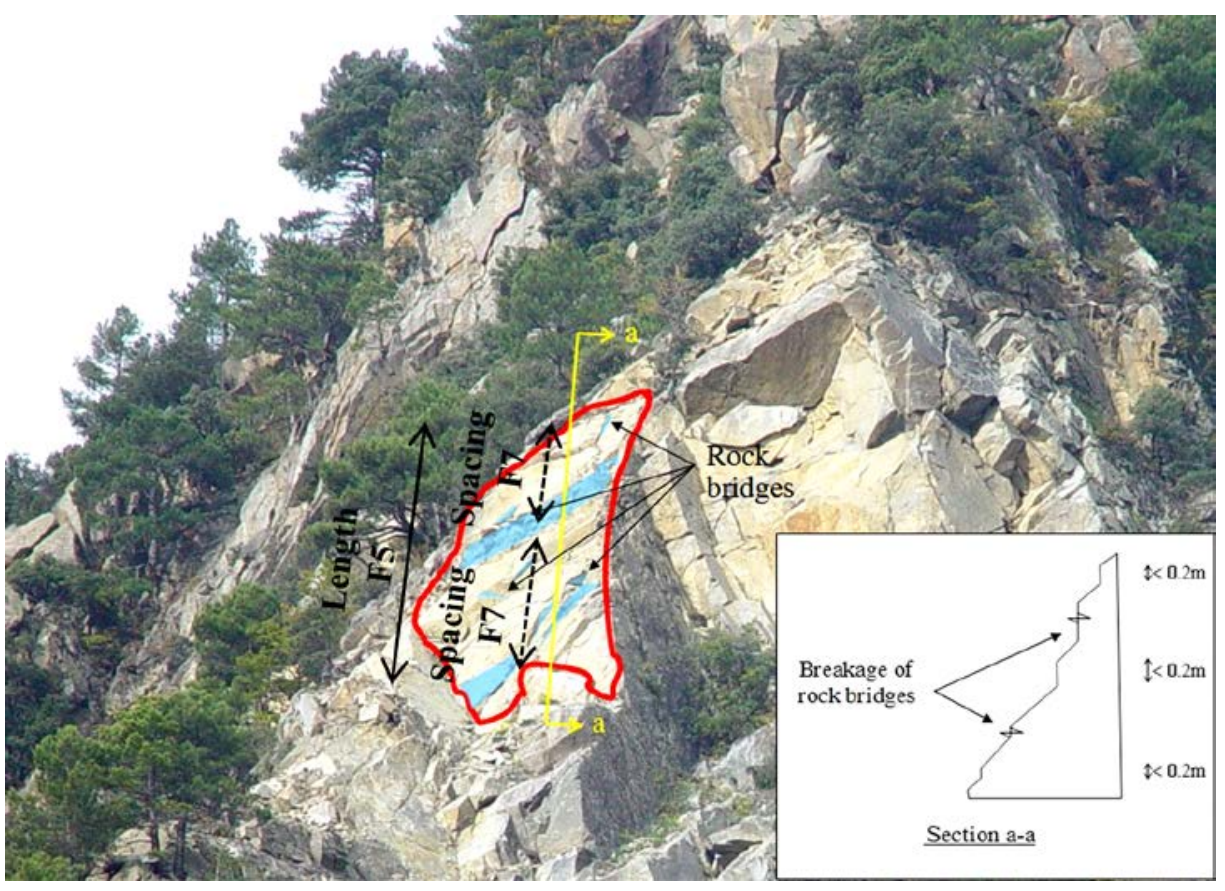

Fig. 11 Indicative basal plane of the discontinuity set F5, including various spacings of F7

\section{Conclusions}

The determination of the maximum rockfall volume which can be expected at a study-site is not a trivial issue, especially for intensely fractured rock masses where several discontinuity sets are present.

In this paper, the results from two previous analyses on the rockfall size distribution, at the chute of Forat Negre, in Andorra, are discussed. The first analysis provides the observed size distribution of the rockfall scars, and it is an empirical evidence of past rockfalls. The second one calculates the kinematically detachable rock masses, indicating hypothetical rockfalls that might occur in the future. Despite the two diverse approaches in the analysis of the rockfall size distribution, the difference between the scar volumes ( $3000 \mathrm{~m}^{3}$ approximately) and the kinematically detachable rock masses ( 25000 or $50000 \mathrm{~m}^{3}$, respectively for prismatic and cubic volumes) is limited to 1 order of magnitude. The comparison provided an insight into the critical factors that affect the maximum realistic rockfall volume, which can be expected at the study-site.

The persistence of the discontinuity sets is a key factor for the volume of big rockfall events. In the study area, the discontinuity set F7 exerts a control over the length of the planes of the discontinuities F3 and F5 and implies a limitation on their persistence. In fact, in most cases, the length of the planes 
$\mathrm{F} 3$ and F5 coincides with the spacing of F7. This leads to the conclusion that the maximum credible rockfall volume should be considerably lower than the greatest kinematically detachable rock mass, as their detachment as a whole is repeatedly restricted by the presence of F7, when it is estimated without consideration of the persistence of the basal planes.

Still, this volume restriction can be overcome to some extent. As the greatest basal planes of the scars indicate, the formation of basal planes across more than one spacings of $\mathrm{F} 7$ is possible. This may occur either along continuous sliding planes or via step-path failures, which might imply pre-existing discontinuities or minor brittle failures. In that case, the spacing of the basal planes is a determining factor for the maximum volume. As a conclusion, the key factor for the determination of the maximum credible volume at the study-site is the maximum realistic length of the basal planes, penetrating into the rock mass, their spacing, and, if applied, the contribution of the rock bridges to the overall rock mass resistance.

\section{Acknowledgments}

This work has been realized with the support of the fellowship "Ayudas Fundación BBVA a Investigadores, Innovadores y Creadores Culturales" by the Foundation BBVA to the first author and within the framework of the research project RockRisk financed by the Spanish Ministry of Economy and Competitiveness (BIA2013-42582-P) and by the Government of Andorra (Edicte de 10/04/2013, BOPA nำ18 17/04/2014).

\section{References}

Abbruzzese JM, Sauthier C, Labiouse V (2009) Considerations on Swiss methodologies for rock fall hazard mapping based on trajectory modelling. Nat Hazards Earth Syst Sci 9(4):1095-1109

Abellán A, Vilaplana JM, Calvet J, García-Sellés D, Asensio E (2011) Rockfall monitoring by Terrestrial Laser Scanning - case study of the basaltic rock face at Castellfollit de la Roca (Catalonia, Spain), Natural Hazards \& Earth System Science, 11, 829-841

Agliardi F, Crosta GB, Frattini P (2009) Integrating rockfall risk assessment and countermeasure design by 3D modelling techniques. Nat Hazards Earth Syst Sci, 9(4), 1059-1073

Barlow J, Lim M, Rosser N, Petley D, Brain M, Norman E, Geer M. (2012) Modeling cliff erosion using negative power law scaling of rockfalls.Geomorphology, 139, 416-424

Bordonau, J. (1992) Els complexos glacio-lacustres relacionats amb el darrer cicle glacial als Pirineus. Geoforma Ediciones, Logroño, 251

Brady BHG, Brown ET (1992) Rock Mechanics for Underground Mining. Chapman \& Hall, London

Brideau MA, Yan M, Stead D (2009) The role of tectonic damage and brittle rock fracture in the development of large rock slope failures. Geomorphology, 103(1), 30-49

Budetta P, De Luca C, Nappi M (2015) Quantitative rockfall risk assessment for an important road by means of the rockfall risk management (RO. MA.) method. Bulletin of Engineering Geology and the Environment. 1-21 
Copons R (2005) Avaluació de la perillositat de caiguda de blocs a Andorra la Vella (Principat d'Andorra). Monografia del CRECIT. Ed. Centre de Recerca en Ciències de la Terra (CRECIT). Sant Julià

Copons R, Vilaplana JM, Corominas J, Altimir J, Amigó J (2005) Rockfall hazard management policy in urban areas: the Andorran experience. In Landslide Hazard and Risk (Ed. T.Glade, M.Anderson and M.Crozier). John Wiley \& Sons Press. 675-698

Corominas J, Copons R, Moya J, Vilaplana JM, Altimir J, Amigó J (2005) Quantitative assessment of the residual risk in a rockfall protected area. Landslides, 2(4): 343-357

Corominas J, van Westen C, Frattini P, Cascini L, Malet J-P, Fotopoulou S, Catani F, Van Den Eeckhaut M, Mavrouli O, Agliardi F, Pitilakis K, Winter MG, Pastor M, Ferlisi S, Tofani V, Herva's J, Smith JT (2014) Recommendations for the quantitative analysis of landslide risk. Bull Eng Geol Environ 73(2): 209-263

Dussauge-Peisser C, Helmstetter A, Grasso JR, Hantz D, Desvarreux P, Jeannin M, Giraud A (2002). Probabilistic approach to rock fall hazard assessment: potential of historical data analysis. Natural Hazards and Earth System Science. 2(1/2): 15-26

Dussauge C, Grasso JR, HelmstetterA (2003) Statistical analysis of rockfall volume distributions: Implications for rockfall dynamics. Journal of Geophysical Research: Solid Earth, 108(B6)

Einstein HH, Veneziano D, Baecher GB, O'reilly KJ (1983) The effect of discontinuity persistence on rock slope stability. In International journal of rock mechanics and mining sciences \& geomechanics abstracts. 20(5): 227-236. Pergamon

Elmouttie MK, Poropat GV (2012) A method to estimate in situ block size distribution. Rock mechanics and rock engineering. 45(3): 401-407

Ferlisi S, Cascini L, Corominas J, Matano F (2012). Rockfall risk assessment to persons travelling in vehicles along a road: the case study of the Amalfi coastal road (southern Italy). Natural hazards, 62(2): 691-721

Ferrari F, Thoeni K, Giacomini A, Lambert C (2015) A new rockfall hazard assessment methodology for open-pit coal mines. Bowen Basin Symposium 2015 - Bowen Basin and Beyond, At Brisbane, Australia. October 2015

Ferrero AM, Migliazza M, Roncella R, Rabbi E (2011) Rock slopes risk assessment based on advanced geostructural survey techniques. Landslides,8(2), 221-231

Frayssines M, Hantz D (2006) Failure mechanisms and triggering factors in calcareous cliffs of the Subalpine Ranges (French Alps). Engineering Geology. 86(4): 256-270

Jennings JE (1970) A Mathematical theory for the calculation of the stability of slopes in open cast mines. Planning of Open Pit Mines. Proceedings. Johannesburg., 87-102

Hantz D, Vengeon JM, Dussauge-Peisser C (2003) An historical, geomechanical and probabilistic approach to rock-fall hazard assessment. Natural Hazards and Earth System Science, 3(6), 693-701

Hoek E, Bray JD (1981) Rock slope engineering. CRC Press

Hungr O, Evans SG, Hazzard J. (1999) Magnitude and frequency of rock falls and rock slides along the main transportation corridors of southwestern British Columbia. Canadian Geotechnical Journal, 36(2), 224-238

Jaboyedoff M, Oppikofer T, Abellán A, Derron MH, Loye A, Metzger R, Pedrazzini A (2012) Use of LIDAR in landslide investigations: a review.Natural hazards, 61(1): 5-28

Kalenchuk KS, Diederichs MS, McKinnon S (2006) Characterizing block geometry in jointed rockmasses. International journal of rock mechanics and mining sciences. 43(8): 1212-1225

Kim BH, Cai M, Kaiser PK, Yang HS (2007). Estimation of block sizes for rock masses with non-persistent joints. Rock mechanics and rock engineering, 40(2): 169-192 
Lambert C, Thoeni K, Giacomini A, Casagrande D, Sloan S (2012) Rockfall hazard analysis from discrete fracture network modelling with finite persistence discontinuities. Rock mechanics and rock engineering 45(5): 871-884

Lari S, Frattini P, Crosta GB (2014) A probabilistic approach for landslide hazard analysis. Engineering Geology, 182, 3-14

Li ZH, Huang HW, Xue YD, Yin J (2009) Risk assessment of rockfall hazards on highways. Georisk, 3(3): 147-154

Lu P (1997) The characterisation and analysis of in-situ and blasted block size distributions and the blastability of rock masses. Thesis of PhD, Queen Mary, University of London. Available online at https://qmro.qmul.ac.uk/ispui/handle/123456789/1626 (last accessed on 25 February 2016)

Lu P, Latham JP (1999) Developments in the assessment of in-situ block size distributions of rock masses. Rock mechanics and rock engineering. 32(1): 29-49

Macciotta R, Martin CD, Cruden DM (2015) Probabilistic estimation of rockfall height and kinetic energy based on a three-dimensional trajectory model and Monte Carlo simulation. Landslides, 12(4), 757-772

Malamud BD, Turcotte DL, Guzzetti F, Reichenbach P (2004) Landslide inventories and their statistical properties. Earth Surface Processes and Landforms, 29(6), 687-711

Markland JT (1972) A useful technique for estimating the stability of rock slopes when the rigid wedge slide type of failure is expected Imperial College Rock Mechanics Research Reprints 19 pp 10

Mavrouli O, Corominas J, Jaboyedoff M (2015) Size Distribution for Potentially Unstable Rock Masses and In Situ Rock Blocks Using LIDAR-Generated Digital Elevation Models. Rock Mechanics and Rock Engineering, 48(4): 1589-1604

Palmström A (1982) The volumetric joint count - a useful and simple measure of the degree of jointing. Proc. int. congr. IAEG. New Delhi. $221-228$

Palmström A (2005) Measurements of and correlations between block size and rock quality designation (RQD). Tunnelling and Underground Space Technology, 20(4), 362-377

Palmström A, (2001) Measurement and characterization of rock mass jointing. In In-situ characterization of rocks (Ed Sharma VI, Saxena K). A. A. Balkema publishers

Picarelli L, Oboni F Evans SG, Mostyn G, Fell R (2005) Hazard characterization and quantification. Landslide risk management. 27-62

Ruiz-Carulla R, Corominas J, Mavrouli O (2015b) A methodology to obtain the block size distribution of fragmental rockfall deposits. Landslides. 12(4):815-825

Ruiz-Carulla R, Corominas J, Mavrouli O (2015a) An empirical approach to rockfall fragmentation. Eurock 2015 - ISRM European Regional Symposium - the 64th Geomechanics Colloquy, 7-10 October, 2015, Salzbourg, Austria

Santana D, Corominas J, Mavrouli O, Garcia-Sellés D (2012) Magnitude-frequency relation for rockfall scars using a Terrestrial Laser Scanner. Engineering Geology, 145: 50-64

Saroglou H, Marinos V, Marinos P, Tsiambaos G (2012). Rockfall hazard and risk assessment: an example from a high promontory at the historical site of Monemvasia, Greece. Natural Hazards and Earth System Sciences, 12(6): 1823-1836

Stead D, Eberhardt E, Coggan JS (2006) Developments in the characterization of complex rock slope deformation and failure using numerical modelling techniques. Engineering Geology, 83(1): 217-235 
Sturzenegger M, Stead D (2009) Quantifying discontinuity orientation and persistence on high mountain rock slopes and large landslides using terrestrial remote sensing techniques. Natural Hazards and Earth System Science, 9(2), 267-287

Turcotte DL, Malamud BD, Guzzetti F, Reichenbach P (2002) Self-organization, the cascade model, and natural hazards. Proceedings of the National Academy of Sciences, 99(suppl 1). 2530-2537

Wyllie DC, Mah, C. (2004). Rock slope engineering. CRC Press.

Yarahmadi Bafghi AR, Verdel T (2003). The key group method. International journal for numerical and analytical methods in geomechanics, 27(6): 495-51 